\title{
DISCURSO E POLÍTICAS DE IDENTIFICAÇÃO CULTURAL: ESTUDO DE UMA COMUNIDADE PORTUGUESA
}

\author{
Clara SARMENTO \\ Centro de Estudos Interculturais (CEI) - Instituto Supeior de \\ Contabilidade e Administração do Porto (ISCAP)
}

RESUMEN: Este trabajo localiza los orígenes político-ideológicos que determinan la retórica de la representación etnográfica de la cultura popular portuguesa a lo largo del siglo XX. La conocida cultura de las monografías ha generado una serie de discursos organizados que asumen la dimensión simbólica y comunicacional del poder instituido y generan un marco narrativo-normativo que todavía forma parte de la ideología nacional. Tomaremos como ejemplo el "barco moliceiro"1, embarcación tradicional de la ría de Aveiro, un gran estuario en la desembocadura del río Vouga localizado en la costa occidental de Portugal. El poder político e ideológico dominante se apropió de esta práctica artística popular, la transformaron y la introdujeron en un discurso de corte folclorista erudito convirtiéndola en un símbolo que reforzaba la idea de la Nación homogénea.

PALABRAS CLAVE: Discurso, Representación, Cultura Popular, Folclore, Portugal, Siglo XX, Ría de Aveiro, Barco Moliceiro.

ABSTRACT: This work studies the political and ideological features that influenced the discourse of ethnographical representation of Portuguese popular culture, along the $20^{\text {th }}$ century. The so-called "culture of monographs" generated a series of highly organized discourses that assumed the symbolic and communicational dimension of the instituted power and created a narrative/normative niche of their own, which still plays a certain role in the national ideology. Here, we use the case of the "moliceiro" boat, a traditional type of boat of the Portuguese Ria de Aveiro, river Vouga's lagoon-estuary on the Western coast of Portugal. The agents of political and ideological power appropriated this popular artistic practice, which was manipulated and included in the erudite discourse on national folklore, a symbol of the homogeneous ideal of the Nation.

KEYWORDS: Discourse, Representation, Popular Culture, Folklore, Portugal, 20 ${ }^{\text {th }}$ Century, Ria de Aveiro, Moliceiro Boat.

\footnotetext{
${ }^{1}$ Barcos que recogen algas de la ría y las utilizan como abono para la agricultura. Las embarcaciones presentan una forma característica.
} 


\section{INTRODUÇÃO}

Este trabalho procura situar as confluências político-ideológicas determinantes na retórica da representação etnográfica da cultura popular portuguesa, ao longo do século XX e até à actualidade. A chamada "cultura das monografias" tem sido geradora de uma série de discursos organizados que assumem a dimensão simbólica e comunicacional do poder instituído e criam um lugar narrativo/normativo, que faz ainda parte do todo ideológico oficial nacional. Para tal, vamos utilizar o exemplo do chamado "barco moliceiro", tipo de embarcação tradicional da Ria de Aveiro, designação corrente da laguna-estuário do rio Vouga, na costa ocidental de Portugal.

A Ria de Aveiro constitui um vasto lençol de água que se estende ao longo da Beira Litoral portuguesa desde o concelho de Ovar (a Norte) até ao de Mira (a Sul), separado do oceano pela linha de dunas que o limita a poente. Com quarenta e sete quilómetros de extensão, a Ria de Aveiro atinge uma largura máxima de sete quilómetros, apesar do progressivo assoreamento.

O barco moliceiro é o tipo de embarcação destinada à colheita e transporte da vegetação subaquática da Ria de Aveiro, vulgarmente designada por "moliço", utilizada como fertilizante na transformação das dunas em terra de cultura. A área geográfica da sua actuação abrange toda a superfície da Ria. De fundo plano, sem quilha e de pequeno calado, o moliceiro é construído em madeira de pinho. Os meios de propulsão tradicionais são a vela, a vara ou a sirga. Uma das características mais originais do barco moliceiro é o conjunto de quatro diferentes painéis de proa e popa que o adornam, pintados directamente sobre a madeira do barco, prática artística ancestral sem paralelo na cultura popular portuguesa. Os painéis dos moliceiros constam de um desenho policromado, enquadrado por cercaduras geométricas e rematado por uma legenda-comentário, formando uma mensagem ilustrada-escrita una e indivisível. São de uma extrema variedade estas vistosas pinturas, que retratam cenas e personagens religiosas, populares ou históricas, mais ou menos caricaturizadas, segundo o talento do artista (ver Imagem 1 e 2).

Encontramos motivos claramente estereotipados nos temas religiosos e grande diversidade nos temas profanos. A religião é a popular e/ou a transmitida pelas instituições. Na vida quotidiana, o actor social é captado no seu diálogo com a natureza, o trabalho, os animais domésticos ou o sexo oposto. O moliceiro pode também focar a própria faina ou referir as condições ecológicas do seu campo de acção. O humor popular gera a maior diversidade de painéis, os predilectos do espectador. Os painéis dos moliceiros nascem da cultura ligada a um ecossistema 
agro-marítimo-fluvial autónomo, que filtra e adapta as diversas influências recebidas ao longo dos tempos. Ao abrigo do fatalismo das vizinhas comunidades piscatórias, o meio rural-lacustre da Ria de Aveiro propiciou o desenvolvimento de uma visão crítica, esclarecida e humorística, sob a forma de arte, numa permanente união da tradição com a modernidade.

A função do barco moliceiro alterou-se profundamente aos longo das últimas décadas. $\mathrm{O}$ antigo instrumento basilar de toda a economia de uma região tornou-se numa mera atraç̧ão turística, um símbolo cuja preservação depende da boa vontade e capacidade financeira de cada proprietário. A poluição, a evolução económica e a emigração afastaram milhares de pessoas desta forma singular de vida. Os fertilizantes químicos tomaram o lugar do moliço no cultivo dos solos arenosos, a indústria do sal entrou em decadência, e as estradas roubaram a função do moliceiro enquanto meio de transporte das populações ribeirinhas. Em 1935, havia cerca de mil moliceiros registados na Capitania do Porto de Aveiro; hoje restam cerca de quarenta. A construção naval quase cessou durante as décadas de emigração massiva de 1960 e 1970 mas, desde meados da década de 1980, os moliceiros foram recuperados como bens culturais. Com frequência, câmaras municipais, autoridades locais e entidades privadas encomendam novos moliceiros aos artesãos sobreviventes, para fins turísticos; para passeios pela Ria de Aveiro; para exposição em museus locais, nacionais e estrangeiros, e para exibição num dos canais da cidade de Aveiro, como exemplo glorioso do património cultural da região. A tradição do moliceiro não está condenada a desaparecer porque este barco soube adaptar-se a uma nova realidade económica e social, assegurando assim a sua sobrevivência e até eventual multiplicação. Pelo contrário, se o moliceiro tivesse persistido em trabalhar apenas para um mundo rural em extinção, este barco estaria há muito sentenciado a um fim inevitável.

\section{A EVOLUÇÃO HISTÓRICA DO TEXTO ETNOGRÁFICO E A ALEGORIA DA TRADIÇÃO}

Enquanto práticas culturais populares, a exploração da vegetação aquática da Ria de Aveiro, a construção artesanal de embarcações moliceiras e a respectiva decoração foram naturalmente objecto de estudo em textos de intuito etnográfico, desde os seus primórdios em Portugal. No entanto, a maior parte desses textos careceu de contextualização sócio-económica e baseou-se em escassa pesquisa documental e deficiente conhecimento do terreno. Ao longo do século XX, o contacto efectivo com os protagonistas da cultura popular foi muitas vezes limitado e os materiais preferencialmente recolhidos em fontes literárias e em informações veiculadas por informantes cultos, no sentido académico da palavra. 
Invariavelmente construídas em redor do tema da autenticidade do passado e da tradição, as descrições etnográficas versando a comunidade popular da Ria de Aveiro acabaram por ser utilizadas em proveito da ideologia fascista do Estado Novo (1933-1974) e seu líder António Oliveira Salazar (1889-1970), como alegoria da beleza dos costumes do humilde povo português - a conservar a todo o custo - e da nobreza da sua ascendência, fabricando se necessário todo um mito das origens.

Fruto da citação mútua, da reverência pelos autores precedentes, sem verificação actualizada, as monografias reproduziram durante décadas conceitos e conclusões parcelares, distantes (quando não claramente opostos) da prática real. Com uma retórica saudosista, valorativa, moralizante e, muitas vezes, mais poética do que científica, a questão da decadência do presente frente à riqueza do passado estabeleceu-se como argumento incontestável logo desde as primeiras décadas do século XX. Contudo, não se verificou uma evolução notável nas monografias publicadas nas últimas décadas desse mesmo século. Mas tal constatação deve-se ao facto de as monografias mais recentes serem da autoria de amadores, cuja única habilitação é o conhecimento empírico da região ou o prestígio local. Tais monografias são invariavelmente publicadas em edição de autor ou patrocinadas pelas autarquias.

Em 1885, Teófilo Braga observa O Povo Português nos seus Costumes, Crenças e Tradições, como se de um mundo exótico e desconhecido por vezes se tratasse. A página etnográfica nasce de uma breve deslocação "não longe da cidade do Porto", onde porém "tudo surpreende, tudo diverge dos aspectos a que os nossos olhos andam acostumados; o rio, a capital, as outras cidades muito mais ainda, as casas, os hábitos, a vegetação"² É um povo sem nome, observado de longe, de relance, com sincera surpresa, uma realidade com a qual o homem de letras burguês sempre coexistiu mas de que mal se apercebera até então. Ao referir a exploração do moliço, Teófilo Braga socorre-se do artigo de Carlos Faria, "Folhetim", publicado em Povo Português: Folha Republicana da Beira Baixa, entre 1882 e 1884, e que constitui a mais antiga referência escrita até agora localizada à decoração pictórica do moliceiro:

Na ria de Aveiro, usam-se os barcos moliceiros, construções obesas, de proa e ré contraídas e que servem para o transporte das algas impropriamente chamadas moliço, pois que elas não podem servir para as palhoças e constituem apenas um riquíssimo adubo para a agricultura, etc.

\footnotetext{
2 Braga, T. (1985-1986 [1885]). O Povo Português nos seus Costumes, Crenças e Tradições, volume I. Lisboa: Publicações Dom Quixote, p. 83.
} 
Estes barcos aparecem por centenas na sua feira (25 de Março) sarapintados na popa e proa com pessoas reais e animais disformes. ${ }^{3}$

Nesta passagem pioneira, destaca-se o juízo de valor fundamentado na experiência prévia do sujeito ciente da sua autoridade e numa generalização que não leva em conta as variantes próprias do vocabulário local. Destaca-se igualmente a desvalorização estética da arte popular, que não é ainda alegorizada como expressão máxima da autenticidade e beleza das tradições que contêm em si a essência do ser português.

Em 1896, a etnografia ensaiava os seus primeiros passos no país, ainda sem sistematização definida, limitando-se à recolha de material e ao confronto incipiente de um ou outro elemento com fenómeno idêntico de além fronteiras. É desse mesmo ano a primeira tentativa séria de compreensão e de isolamento da etnografia no quadro das ciências que em Portugal se regista. Provocou o seu aparecimento a celebração do centenário do descobrimento da Ìndia, projectada para o ano imediato, e subscreveu-a Adolfo Coelho, intitulando-a "Exposição Ethnographica Portugueza - Portugal e Ilhas Adjacentes”, a realizar em Lisboa e que não se efectivou.

Mas em Aveiro, a 30 de Maio daquele mesmo ano de 1896, o bi-semanário local Campeão das Províncias insere uma carta dirigida pelo engenheiro dos serviços hidráulicos Melo de Matos ao Barão de Cadoro, acerca de uma exposição alusiva à Ria de Aveiro. O Barão de Cadoro havia encarregado Melo de Matos da missão de organizar o programa para uma exposição dos produtos da Ria de Aveiro, exposição essa que também nunca chegou a realizar-se. Nesse programa, onde o aspecto iconográfico assume especial relevo, a segunda secção debruça-se exclusivamente sobre a colheita de moliço, ilustrada com diversas peças originais, modelos, plantas e fotografias. Melo de Matos profere o seu discurso sobre a necessidade premente de preservar as genuínas tradições populares portuguesas, chamando a atenção para os "[...] costumes que têm resistido até agora à tendência uniformizadora da civilização, para indústrias caseiras dignas de apreço e em vésperas de se extinguirem, porque já quase que se podem classificar como modos de viver que não dão para viver, para formas de construção naval que talvez, em breve, se percam de todo, para manifestações artísticas populares reveladas nos vestuários, nas jóias, nas festas e nos barcos”"

${ }^{3}$ Idem, p. 135.

${ }^{4}$ Citado em: Madahil, A. (1947). “A Exposição Alusiva à Ria de Aveiro projectada em 1896 pelo Barão de Cadoro e pelo Engenheiro Melo de Matos”. Arquivo do Distrito de Aveiro, vol. XIII, p. 15. 
Na sua carta, Melo de Matos descreve aquilo que, na realidade, é o programa que norteou os primórdios da etnografia em Portugal: os costumes populares moribundos, frente à ameaça globalizante da civilização; a intervenção de emergência do etnógrafo; a organização de exposições de âmbito local, incipientes iniciativas museológicas onde a quantidade dos objectos se sobrepõe à qualidade científica da sua organização, catalogação e apresentação. Um programa que, nas suas motivações e métodos de trabalho, ainda actualmente subsiste na organização de muitas monografias e museus locais.

Mas é a atenção conferida pelo autor aos painéis do moliceiro que aqui merece maior destaque, uma vez que lhes confere verdadeiro valor artístico, sem os qualificar com os termos disfóricos empregues apenas três anos antes por Carlos Faria e reproduzidos por Teófilo Braga. Melo de Matos reconhece também o seu carácter representativo e expressivo do modo de viver e pensar da região: “[...] as indústrias da ria, do modo de viver dos seus habitantes, tentando coordenar as suas indústrias caseiras, os documentos iconográficos estampados nas proas dos barcos moliceiros, que sulcam estas extensas águas, fixando as formas, talvez em breve perdidas, das embarcações desta região, as velas que as movem, as redes com que exploram a fauna das suas águas, as casas em que se abrigam aqueles que vivem aqui" 5 .

Melo de Matos envolve a descrição do seu projecto em comentários onde ressalta a tradição alegorizada enquanto espelho da identidade nacional que, quando comparada com manifestações homólogas no estrangeiro, só deverá sair valorizada na sua superioridade. Mais do que da identidade, encontrar-se-à na arte popular a alegoria do orgulho nacional e, nos painéis dos moliceiros, um exemplo da singular noção estética da "raça".

Logo em 1905, Luís de Magalhães publica na Revista Portugália: Materiaes para o Estudo do Povo Portuguez o artigo "Os Barcos da Ria de Aveiro”, primeiro ensaio de descrição sistemática destas embarcações fluviais, com tentame de contextualização geográfica, social e económica. Esta primeira concepção alargada da etnografia encontra-se, na generalidade, na orientação editorial imprimida por Rocha Peixoto à Portugália, por contraste com uma etnografia que, quer anterior quer posteriormente, se mostra mais interessada nos objectos do que no contexto em que eles são produzidos ou por referência ao qual fazem sentido.

Após breve referência à hipotética origem mediterrânica dos barcos da Ria de Aveiro, Luís de Magalhães ressalva prudentemente: “Sem nos internarmos n’uma

${ }^{5}$ Idem, p. 19. 
questão de origens, onde só poderiamos estabelecer inconsistentes hypoteses, observemos estes barcos, um a um”6. Não se nota neste texto a necessidade de encontrar uma origem mítica, enobrecedora, que justifique o valor patrimonial atribuído às embarcações, nem se procura criar uma ficção em seu redor, como sucederá em obras posteriores. Neste momento, a etnografia preocupa-se preferencialmente com a "pureza ethnica" da "família politica e historica, que é a nação portugueza”. Na tradição popular procura-se a identidade de um país em convulsão, nas vésperas da queda da monarquia.

O projecto de Melo de Matos, embora nunca realizado, teve continuadores entre os estudiosos da região aveirense, que defenderam a sua concretização sob a forma permanente de museu regional. É o caso de Alberto Souto (posteriormente director do Museu Regional de Aveiro) que, em 1929, publica Etnografia da Região do Vouga (Beira-Litoral): Memória Justificativa sobre a Criação de um Instituto de Estudos e de um Museu Etnográfico com Sede em Aveiro. Sem a projecção de outras obras, instituídas como referências incontornáveis e citadas ao longo de décadas, a Etnografia da Região do Vouga constitui o resumo ideal daquilo que é a etnografia em Portugal no início do século XX.

Os comentários de Souto sobre a rude pobreza das tradições populares portuguesas não estão isolados no panorama etnográfico da época. Contudo, serão sempre as passagens de retórica encomiástica - em que Alberto Souto é parco aquelas que vão perdurar, mesmo se fundamentadas em observações imprecisas. A pobreza do folclore nacional motiva a seguinte passagem, de contornos críticos, republicanos na referência ao domínio austero da igreja católica, logo dificilmente (re)formulável após a instauração do Estado Novo:

Não tem, bem eu sei, o nosso povo uma originalidade de costumes, habitos e tradições [...]. É relativamente pobre o nosso Folclore. O romance, a lenda, a canção, a dansa não teem nesta região baixa da Beira-Marítima uma particularidade tal que enriqueça a bagagem do investigador e prove faculdades inventivas tipicas num povo que experimentou variadissimas influencias etnicas. A arte popular é pobre. A casa é geometrica e despida de adornos. Os utensilios agricolas são simples e lavados de ornatos. Os ritos cultuais são sobrios e não muito fora da vulgar e ortodoxa liturgia do catolicismo dominante. ${ }^{7}$

\footnotetext{
${ }^{6}$ Magalhães, L. (1905). “Os Barcos da Ria de Aveiro”. Portugália: Materiaes para o Estudo do Povo Portuguez, tomo II, fasc. 1, p. 53.

${ }^{7}$ Souto, A. (1929). Etnografia da Região do Vouga (Beira-Litoral): Memória Justificativa sobre a Criação de um Instituto de Estudos e de um Museu Etnográfico com Sede em Aveiro. Coimbra: Coimbra Editora, p. 27.
} 
Desta passagem, os textos submetidos ao regime ideológico dominante após 1933 reterão apenas a ameaça que o "nivelamento da civilisação cosmopolita" representa, face à genuína essência da Nação que há que preservar, se necessário pelo isolamento e estagnação compulsória. Mais próximo da retórica de Melo de Matos do que da objectividade etnográfica de Luís de Magalhães, Alberto Souto também defende os costumes populares moribundos, frente ao progresso, e a intervenção de emergência do etnógrafo: "urge descrever, inventariar e analisar”; "Mas não há tempo a perder, porque o tempo devora e consome"; "é preciso salvar [...] a graça ingénua da arte popular"; "Recolher, pois, sem perda de tempo, porque a época é de velocidade e a velocidade moderna desmantela rapidamente o passado, quando este se não cultiva”. A retórica é maniqueísta, o discurso estrutura-se em binómios simplistas, de alcance difuso: "renovação" - "perda de tradições"; "aldeia utilitarista” - "poetisar a vida rural”; "desenvolvimento populacional e económico" - "chateza e anodinismo etnográficos”.

Porém, Alberto Souto partilha com Luís de Magalhães a certeza de que é nos costumes populares que se revela a identidade da raça portuguesa, da entidade colectiva: "[...] recolher tudo aquilo que constitue a documentação do caracter do nosso Povo e o que nele, durante anos e seculos, constituiu uma revelação da sua alma", . O conservadorismo do texto etnográfico defende o isolamento desses testemunhos no espaço e no tempo, ao abrigo não só de influências estrangeiras mas também de um eventual processo de evolução dentro das espécies de embarcações existentes: "Um artista que fosse chamado para embelezar a obra do construtor, não delinearia melhor, nada teria a corrigir, porque nestes barcos não ha que modificar, ha apenas que copiar bem, sem alterar em nada o seu pefil airoso, gracioso e cheio de caracter [...] não se pode modificar de maneira alguma, nem substituir seja por que modelo fôr, o barco que a Ria gerou, impondo-lhe uma estética natural e inconfundível”"

António Gomes da Rocha Madahil transcreve a carta de Melo de Matos em 1947 mas, em 1934, publicara já Etnografia e História: Bases para a Organização do Museu Municipal de Ílhavo, apresentando também o seu programa para a organização de um museu regional. Na realidade, tal museu, inaugurado a 8 de Agosto de 1937, com organização e direcção do próprio Rocha Madahil, tal como é descrito em Etnografia e História e no Guia de Portugal de Sant'Anna Dionísio (1944), em pouco difere da exposição planeada na carta de Melo de Matos, em

\footnotetext{
${ }^{8}$ Idem, pp. 27-33.

${ }^{9}$ Idem, ibidem.

${ }^{10}$ Idem, pp. 44-5.
} 
1896. Madahil vai reproduzi-la dez anos depois da inauguração do Museu de Ílhavo, como uma espécie de aprovação histórica, de nobre precedente do seu projecto.

A organização do Museu, tal como anunciada em Etnografia e História, mostrase ciente da especificidade da flora aquática da Ria de Aveiro, bem como das suas embarcações, merecedoras de seç̧ões ou salas autónomas. Para todos os objectos que considera característicos da região (embarcações, painéis dos moliceiros, exvotos marítimos, cangas decoradas), Madahil procura uma origem histórica, uma influência de outros povos. Justifica o projecto museológico no facto de o conhecimento e a celebração artística da região serem formas de ensinar o amor à pátria e formula um ensaio de demarcação da área cultural: "Em Cacia veem-se as primeiras tendências para o enfeite, em Ovar são as cangas já estilizadas e recamadas de opulentos desenhos e coloridos. [...] O Vouga é, um pouco, como nota Raúl Brandão, a linha onde tudo muda - costumes, tradições, festas”11.

Mas o contacto declaradamente breve e superficial com a realidade do terreno e o preconceito que leva o autor a encarar os objectos etnográficos como "curiosidades" estão na base de uma das passagens mais citadas de sempre sobre a decoração do moliceiro, misto de prosa poética e imprecisão:

A proa do moliceiro - o mais lindo barco da Ria - é uma peça excepcional, com valor e significado próprios; constitue, verdadeiramente, a parte nobre do barco, a mais expressiva e a mais representativa também; imprime-lhe carácter. Nenhuma outra o construtor afaga tanto, velando pela pureza da linha e do recorte que lhe são peculiares; na proa concentra o pintor todo o seu simbolismo: a sua mais garrida cercadura de semi-círculos encadeados ou de rosetas sexfoliadas, os mais luzidos painéis, as mais espirituosas legendas; o simbolismo da ré já é menor, a pintura mais reduzida e simplificada, menos cuidada até. Os dois painéis da proa e as suas cercaduras são bem a réplica achada pelo íncola da região ao colar de penas de vivo colorido, que certas aves aquáticas, certos palmípedes, apresentam no pescoço, como se, à imagem e semelhança delas, o barco tivesse sido concebido pelo seu remoto criador. E, como na ave, também é esse colar mais extenso e vistoso que as da cauda ou da ponta da asa - o painel da ré. ${ }^{12}$

${ }^{11}$ MADAhIL, R. (1934). Etnografia e História: Bases para a Organização do Museu Municipal de Ílhavo. Ílhavo: Tipografia Casa Minerva, p. 87.

${ }^{12}$ Idem, pp. 57-8. 
A comparação com as penas de “certas aves aquáticas” contrasta com o facto de tal fauna avícola de vivo colorido não existir, na realidade, na Ria de Aveiro. Também a reiterada desvalorização estética dos painéis da ré em comparação com os painéis da proa não está de acordo com as provas iconográficas encontradas nos arquivos e publicações da década de trinta e anteriores (e também posteriores). Com efeito, a profusão ou simplicidade das decorações e legendas varia de embarcação para embarcação segundo o talento do construtor ou pintor mas não dentro da própria embarcação, seguindo um qualquer princípio de subordinação da popa em relação à proa. A observação de Rocha Madahil, que se instituiu como verdade incontestável durante décadas, fundamentar-se-á na maior elevação do painel da proa, com a sua forma mais invulgar do que o quase rectângulo da popa, evocando as figuras de proa dos grandes navios. De igual modo, a tradicional figuração de cavaleiros e soldados no painel de proa evoca imagens de superioridade provenientes da hieraquia social estabelecida. $\mathrm{Na}$ realidade, os painéis da ré oferecem até mais espaço para que o decorador neles crie quadros mais vivos e elaborados, cómicos, maliciosos ou relacionados com a vida quotidiana na Ria.

A imagem positiva do povo e da cultura popular portuguesa, guardiões alegóricos da essência da Nação, nem sempre surge formulada de modo inequívoco. Em 1944, António Nascimento Leitão publica Aveiro e sua Laguna (Vistos Através do Mundo), com o sub-título Estudo Comparativo de Temas Regionais. Apesar da comparação com realidades externas gerar comentários desfavoráveis à pobreza dos costumes populares portugueses, Nascimento Leitão comunga da preocupação de Luís de Magalhães e de Rocha Madahil com a diferenciação “étnica” da região de Aveiro. Enumera detalhes da "raça”, descreve um "tipo" físico e psíquico muito elogiado, como se se tratasse de um povo distante e estranho. Formula a habitual hipótese sobre a origem grega e fenícia deste "tipo étnico", fundamentando-se na proposição “diz a História”, mas sem citar qualquer fonte. Refere apenas as Memórias de Aveiro de Marques Gomes, de 1875, de cuja leitura retira a especulação: “quási se pode sustentar sem medo de errar, que êstes povos aqui viveram, ou pelo menos aqui vieram comerciar”13. Tais suposições repetem-se e citam-se entre si, como se a existência prévia da hipótese de um autor justificasse a hipótese de outro.

Se no povo se encontra o espírito da “raça”, a relevância conferida pelos estudiosos a esta classe de contornos difusos não pode, porém, constituir uma

${ }^{13}$ Leitão, A. N. (1944). Aveiro e sua Laguna (Vistos Através do Mundo). Lisboa: Sá da Costa, p. 184. 
ameaça à ordem social estabelecida. Ao descrever determinadas práticas populares de cariz devocional, onde se incluem as da romaria ribeirinha do S. Paio da Torreira, padroeiro dos moliceiros, Nascimento Leitão tem o cuidado de as classificar como "superstição". Depois do juízo moral (em sintonia com a censura que fora de facto imposta na década de quarenta à romaria de $S$. Paio e sua tradição semi-pagã de banhos de vinho à imagem do Santo, seguidos de fartas libações), segue-se o habitual apontamento saudosista sobre a pureza perdida dos costumes: "Passou o verdadeiro sentimento que movia as gerações anteriores" e "tem já mesmo degenerado a intenção primitiva”. Demora-se, por fim, a delinear uma ambígua diferença entre superstição e "supersticiosidade", esta apanágio daquilo que designa por "classes cultas ou não ignorantes de todo", imbuídas de outro "espírito de época"". As práticas culturais obtêm significados díspares, em função da classe a que pertencem, com a respectiva hierarquização bem demarcada. O valor alegórico das tradições populares nunca poderá ser assumido pela classe que as pratica, num qualquer assomo de emancipação. Deverá ser reconhecido externamente, pelas classes cultas que condescendem em observá-las. No entanto, da leitura de Aveiro e sua Laguna depreende-se que o "espírito de época” vigente na descrição etnográfica de quarenta pouco evoluira desde finais do século XIX.

Luís Chaves, activo colaborador do Secretariado Nacional de Informação (SNI), foi um dos mais prolíficos etnógrafos portugueses de meados do século XX. A sua notável atenção ao barco moliceiro gerou porém uma série de textos de retórica arcaica, baseados em superficial observação e na reformulação de conceitos anteriores. Como se comprova, a etnografia desta época manteve sempre, a par de um envolvimento mais ou menos claro com a política e a ideologia do regime, uma considerável distância em relação às metodologias e aos textos universitários e científicos.

Em 1943, em A Arte Popular: Aspectos do Problema, Luís Chaves segue fielmente o texto de 1934 de Rocha Madahil, transcrevendo a citada passagem sobre a excepcionalidade estética da proa do moliceiro e acrescentando alguns títulos à breve bibliografia sobre a Ria de Aveiro patente em Etnografia e História, que introduz com o comentário de cortesia: "Dos moliceiros falaram, com elegância e simpática delicadeza...”15. A autoridade da voz precedente sobrepunhase à simples observação das fontes iconográficas ou das próprias embarcações em uso na realidade. Na generalidade, Luís Chaves mostra-se preocupado com a

\footnotetext{
${ }^{14}$ Idem, p. 197.

${ }^{15}$ Chaves, L. (1943). A Arte Popular: Aspectos do Problema. Porto: Portucalense Editora, p. 124.
} 
proveniência dos motivos decorativos das embarcações, em duas vertentes: a influência histórica de outros povos (questão relacionada com o "mito das origens") e a inspiração popular ou "influência de feição superior à de índole popular". Sem chegar a formular qualquer conclusão, elabora juízos de valor tão simplistas como "há barcos feios, desprovidos de toda e qualquer feição estética"16.

A tendência para o anacronismo no texto etnográfico português é visível no caso da produção textual da família Pires de Lima. Como se confirma na leitura do capítulo sobre "Origem, época e evolução", da secção "Pintura Popular", no segundo volume de A Arte Popular em Portugal, assinada pelo próprio coordenador da colecção, publicada entre 1968 e 1975:

O povo cria pouco, julgamos mesmo que não pensa em fazer um esforço para criar obra nova e, quando o faz, é sem intenção, sem haver em si um verdadeiro desejo de se libertar de influências estranhas, mas alguma coisa de seu nos traz. Há na sua obra um fundo e uma estabilidade comuns a todo o ser primitivo, a par de certos elementos que a tornam diferente para cada povo e de uma ou outra pequena inovação introduzida de vez em quando. As tradições, levando à persistência de antigos motivos, têm muita importância na arte popular, sendo o esforço do pintor orientado principalmente no sentido de uma assimilação e adaptação de assuntos de uma arte de ordem superior à arte popular. A cópia de pintura de categoria elevada, a cópia de estampas e até mesmo a cópia de cartas de jogar têm papel muito importante como fontes de inspiração do pintor popular que simplifica e estiliza estes assuntos, adaptando-os à sua maneira de sentir e de realizar determinada obra. $^{17}$

Pires de Lima dedica vários parágrafos do capítulo sobre pintura profana em painéis ao moliceiro, descrevendo de forma concisa e factual os seus ornamentos e pinturas, atento às imagens que acompanham o texto. Estabelece um paralelo entre a técnica pictórica dos moliceiros e a dos painéis votivos ou ex-votos, aproximando-os também no assunto, quando perante moliceiros com painéis religiosos. Destaca a preferência do moliceiro pelos "episódios da vida corrente"18 e pelas figuras de reis e personagens políticos. Refere painéis provenientes de moliceiros então patentes no Museu Municipal de Ílhavo e no Museu de Arte Popular de Lisboa. Mas a sua fonte principal são os Estudos Etnográficos de D.

16 Chaves, L. (1958). Os Transportes Populares em Portugal: Carros e Barcos (Tipos e Decorações). Lisboa: Fundação Nacional para a Alegria no Trabalho, Gabinete de Etnografia, p. 35.

17 LimA, F. C. P. (1968-1975). A Arte Popular em Portugal, vol. II, “Pintura Popular”. Lisboa: Editorial Verbo, p. 158.

${ }^{18}$ Idem, p. 128. 
José de Castro, de 1943. Daqui se conclui que, apesar da evidente atenção ao pormenor e da presença de ilustrações, a descrição etnográfica de Pires de Lima não provem da observação directa e/ou participante da realidade, mas sim da observação de peças recolhidas em museus ou de reproduções impressas em fontes bibliográficas, cronologicamente já distantes. Tal como os seus antecessores, o etnógrafo não precisa de se deslocar ao terreno nem de abandonar o universo urbano e livresco para escrever a sua narrativa. A elite culta demarca-se do "povo" a todos os níveis, limitando-se a conferir-lhe os significados alegóricos que melhor servem os seus interesses.

Desta forma, o objecto em estudo é descrito e/ou avaliado mas não contextualizado nem interpretado nos seus múltiplos referentes. E aqui, a retórica de Pires de Lima parece recuar aos inícios do século XX, até ao artigo de Luís de Magalhães na Portugália. Magalhães utiliza também uma linguagem pictórica, minuciosa na descrição das características formais do objecto, sem extrapolações teóricas. Aliás, Magalhães parece ainda mais atento à contextualização sócioeconómica do moliceiro do que Pires de Lima e também mais cauteloso na questão das origens. Bibliograficamente, Pires de Lima apoia-se em D. José de Castro, Luís Chaves, Luís de Magalhães e Rocha Madahil, utilizando fontes cronologicamente balizadas entre 1905 e 1958.

É na citada passagem sobre as “origens” da pintura popular, questão que assume como sendo de difícil análise, que Pires de Lima formula as hipóteses mais anacrónicas, próximas do tom crítico, pleno de preconceitos sócio-culturais, do artigo de Carlos Faria citado por Teófilo Braga em 1885. A arte do "povo" (conceito que permanece por esclarecer) será de tal modo ingénua e infantil que é até desprovida de intenção. Esse ser sem individualidade nem vontade apresenta-se incapaz de um esforço de criatividade, raciocínio e originalidade, limitando-se a imitar, e mesmo assim sem sucesso, a arte superior das classes cultas. A questão da imitação revela-se imprecisa na generalidade, uma vez que a "assimilação e adaptação de assuntos de uma arte de ordem superior à arte popular” não é característica manifesta da pintura popular portuguesa, como se constata, precisamente, no caso dos painéis do moliceiro. Esta passagem, escrita quase no último quartel do século XX, contém um dos mais claros exemplos de paternalismo cultural em relação ao colectivo "povo" formulados desde o século XIX. Longe da exacerbação nacionalista de Rocha Madahil e muito mais explícito na segregação sócio-cultural do que Nascimento Leitão, Pires de Lima parece fechar aqui um ciclo temporal de um século, durante o qual o texto etnográfico português pouco ou nada evoluiu, oscilando apenas entre diferentes graus de alegorização da tradição popular enquanto detentora da pura essência da Nação, com base na descrição dos objectos imediatamente visíveis. 


\section{O MITO DAS ORIGENS E O DISCURSO IDEOLÓGICO-POLÍTICO}

Como se constata, a etnografia portuguesa desenvolveu-se dentro do âmbito de uma orientação cultural estruturada em redor da preocupação obsessiva com o passado e a identidade nacional. Esta convergência resultaria daquilo que Eduardo Lourenço classifica como um persistente "sentimento de fragilidade ôntica" dos intelectuais portugueses em relação ao seu próprio país ${ }^{19}$.

As tradições populares seriam sucessoras e depositárias dos diferentes povos, de origem remota mas incerta e características singulares, que teriam passado pelo território nacional. Nessas tradições repousaria a verdadeira essência da identidade nacional, vista como o produto de remotíssimas originalidades étnicas, bem mais fortes e poderosas do que um conjunto aleatório de acontecimentos políticos e militares. A produção textual subsequente apoia-se numa arreigada retórica nacionalista mas invariavelmente insignificante em termos teóricos. A nota dominante nos textos etnográficos construídos em torno da questão mitificada das origens é a preocupação com a ancestralidade das práticas e características da Nação portuguesa. A construção textual do "mito das origens" equilibra as incertezas da História com a necessidade político-ideológica de enobrecer o passado da Nação e sancionar o mérito dos seus líderes. A fabricação de uma genealogia que remonta a tempos imemoriais estabelece as tradições populares como herdeiras de civilizações antigas, que assim transmitem o prestígio de uma cultura.

Na sua Memória Justificativa, de 1929, Alberto Souto não deixa de declarar que utiliza os costumes populares para descobrir a genealogia e a ascendência das populações locais: "encontrar nos costumes presentes as tradições de antigos mitos, de práticas religiosas e superstições, de inveterados e vetustos usos e os costumes dos povos primitivos” ${ }^{\prime 20}$. Para a questão das origens das práticas lagunares, cita Alexandre Herculano e evoca ancestrais fenícios, gregos e cartagineses, o que lhe permite elaborar as seguintes conclusões impressionistas: "Ha nomes de terras como Arada que teem todo o sabor fenicio. Ha restos de crastos e mamoas, tipos fisionomicos que lembram os gregos e que lembram os berberes”21.

19 Lourenço, E. (1978). O Labirinto da Saudade: Psicanálise Mítica do Destino Português. Lisboa: Dom Quixote, p. 92.

20 Souto, A. (1929). Etnografia da Região do Vouga (Beira-Litoral): Memória Justificativa sobre a Criação de um Instituto de Estudos e de um Museu Etnográfico com Sede em Aveiro. Coimbra: Coimbra Editora, p. 28.

${ }^{21}$ Idem, p. 30. 
Mais ousado na retórica e na evocação de origens míticas é Celestino Gomes, no seu ensaio de 1932, Os Motivos de Decoração Ilhavense, texto composto num estilo ultra-romântico tardio, quase épico. Celestino Gomes ensaia uma definição erudita do conceito de arte, sempre orientada pela questão das origens do "instinto artístico” no ser humano, recuando até à “noite primitiva da história”22. É aí também que localiza a origem dos motivos decorativos da arte popular, que considera serem transmitidos “na voz do sangue” desde o "primitivo ribeirinho” até à actualidade, num instinto próprio do homem popular, assim caracterizado como estando próximo da natureza, do animal, do irracional ${ }^{23}$.

No já referido Etnografia e História, também Rocha Madahil se envolve na demanda das origens míticas do barco moliceiro. Aos ancestrais fenícios, gregos e cartagineses de Alberto Souto, Rocha Madahil contrapõe as influências normandas, reproduzindo uma imagem do petroglifo de Häggeby, encontrado na Suécia. Autores posteriores efectuarão a fusão das hipóteses normandas e mediterrânicas, unanimemente convictos de que a busca das origens é a missão dos etnógrafos.

A questão das origens mitificadas da cultura popular portuguesa - sem qualquer preocupação de fundamentação científica - insere-se na política de ressurgimento étnico, de culto do espírito nacional, levada a cabo pelo Estado Novo. Um dos momentos altos dessa política foi a inauguração do Museu de Arte Popular, em 15 de Julho de 1948. No discurso inaugural, António Ferro - ideólogo do regime e director do Secretariado de Propaganda Nacional - considera o novo Museu como sendo "exemplo de soberania espiritual, da nossa profunda diferenciação, retrato da alma de um povo que não quer renunciar nem à sua graça nem ao seu carácter”,24. A cultura popular ali representada funcionará como uma imagem paradigmática exemplar:

[...] uma escola de bom gosto para os artistas, e onde ricos e pobres se encontram com a verdadeira noção do ser português protagonizada pelo Estado Novo. A necessidade do Museu é justificada pelo seu valor etnográfico, folclórico e propagandístico desta ideia do popular como representação máxima de uma dada noção de nacionalidade. A vertente científica que justificaria a existência formal de tal espécie de acervo é

\footnotetext{
${ }^{22}$ Gomes, C. (1932). Os Motivos de Decoração Ilhavense. Ilhavo: Casa Minerva, p. 11.

${ }^{23}$ Idem, p. 13.

${ }^{24}$ Ferro, A. (1948). Museu de Arte Popular. Lisboa: SNI, 1948, p. 15.
} 
relegada pelos próprios especialistas, como Luís Chaves, para segundo plano. $^{25}$

Luís Chaves é um dos autores que mais páginas dedica à missão patriótica de busca das origens e também um fiel adepto das conjecturas de Alberto Souto e Rocha Madahil, que cita sistematicamente como sendo complementares. Nas obras que publica entre 1943 e 1958, o mito das origens nobres, ancestrais e indefinidas das embarcações tradicionais portuguesas ocupa diversas páginas, sem que se verifique qualquer evolução nos argumentos utilizados.

Em “A Decoração dos Nossos Barcos (Notas de Etnografia)”, a problemática das origens é aplicada às ornamentações pictóricas de moliceiros e seus congéneres. Chaves interpreta-as em diversas categorias, afirmando:

Há decorações, que foram símbolos ou propiciação, e hoje têm carácter de religiosidade, mais ou menos profunda; estão no caso imagens, emblemas, etc. Há decorações, cuja origem animista é conhecida, e hoje são inteiramente ou quási por completo amorfas nêsse campo de superstição; quando o não sejam completamente, persiste a primitividade no subconsciente dos que a mantêm ainda [...] Há decorações de figuras geométricas, isoladas ou agrupadas, que significariam primitivamente sentimentos, ou exprimiriam linguagem simbólica, hoje não conservada; cadeias, tranças, ondas, etc. [...] as faixas, que são alargamento ou fusão de linhas paralelas (rectas ou curvas), representavam idéias ora por imitação realista, ou por interposição simbólica. ${ }^{26}$

As questões mantêm-se: “origem animista conhecida” por quem? Como comprovar a persistência dessa "primitividade no subconsciente dos que a mantêm” ou a existência remota dos significados simbólicos? Como sustentar que “as faixas [...] representavam idéias”, de forma realista ou simbólica? As extrapolações prosseguem na identificação das sequências de semicírculos com as conchas e na comparação dos compartimentos e geometria dos painéis com a geometria das marinhas e canais da Ria. Segundo o autor, as bandeiras dos barcos e das festas, os balões coloridos e os “copos de papel de colorido vivíssimo”27 dos arraiais influenciaram o colorido do moliceiro.

25 Paulo, H. (1994). "Vida e Arte do Povo Português: uma visão da sociedade segundo a propaganda oficial do Estado Novo”. Revista de História das Ideias, vol. 16, pp. 118-19.

${ }^{26}$ Chaves, L. (1945). “A Decoração dos Nossos Barcos (Notas de Etnografia)”. Brotéria, vol. XLI, pp. 46-8.

${ }^{27}$ Idem, p. 52. 
Dada a ausência de conclusões relevantes, este ensaio distingue-se pela formulação de um verdadeiro "anti-mito" das origens, decerto involuntário, antítese das afirmações precedentes, mas muito mais próximo da realidade e da própria opinião dos actores sociais, cuja voz foi sistematicamente silenciada na narrativa etnográfica portuguesa. Luís Chaves sustenta que, tal como existem decorações com sentido religioso, evocativo ou amoroso, também existem decorações "que não passam de meras decorações", motivos simbólicos que representariam "o que quer que fosse" que os acompanhasse ${ }^{28}$.

A dificuldade de verificação da questão das origens aponta aos autores duas orientações possíveis: a fabricação ficcional de um mito ou a elaboração de uma teoria consciente da pluralidade de opções coexistentes e da sua própria falibilidade. Ao contrário dos autores precedentes, é esta a orientação seguida por Octávio Lixa Filgueiras, ao longo da sua vastíssima obra de etnografia e arqueologia naval. Lixa Filgueiras pondera as hipóteses precedentes para a filiação histórica das embarcações lagunares, antes de apresentar a sua teoria: "A linha de influência Ur - Ugarit - Creta ganharia, neste caso, o maior relevo, obrigando-nos a repensar as hipóteses de Schulten àcerca das relações com Tartessos e dos antagonismos desta hipotética antiga área de contacto de Creta com os entrepostos vizinhos fenício-cartagineses" ${ }^{29}$.

Sem se pretender avaliar aqui a consistência das hipóteses de Filgueiras, a sua aproximação à questão das origens distingue-se pelo discurso rigoroso, apoiado em observação cuidada e extensa bibliografia, do qual nasce um claro esforço de teorização. Ao longo da sua obra, são várias as vezes em que descreve com o auxílio de mapas e fotografias recolhidas no terreno a tipologia das embarcações tradicionais portuguesas, de norte a sul do país, organizadas por zonas geográficas e origens, com diagramas das fases de construção e quadros descritivos das embarcações. Sempre muito técnico e factual, Filgueiras não apresenta para o moliceiro qualquer contextualização sócio-cultural, fiel como é à questão das origens e das influências mútuas entre as diversas tipologias de embarcação. Segundo o autor, o moliceiro enquadra-se na categoria "canoas de tábuas de tipo mesopotâmico" ou "próximo oriente", que localiza nas margens e na costa adjacente da Ria de Aveiro.

Esta incessante busca das origens, patente nos estudos sobre o barco moliceiro mas espelho de toda uma orientação da etnografia portuguesa ao longo do século

${ }^{28}$ Idem, pp. 48-50.

29 Filgueiras, O. L. (1981). "Barcos de Pesca de Portugal". Revista da Universidade de Coimbra, vol. XXVIII, p. 361. 
XX, insere-se num discurso pseudo-científico de construção da Nação, que transforma a descrição das tradições populares locais numa tentativa de descrever e fundamentar a própria identidade nacional. A Nação seria uma entidade homogénea, possuidora de um carácter próprio distintivo, de ascendência nobre e mitificada (porque imprecisa e tão difícil de comprovar como de contestar), que se manifestaria através dos costumes populares, fielmente aparentados entre si.

A existência dessa alma colectiva, ancorada num carácter nacional específico, figurava entre os principais argumentos para legitimizar a naturalização do arbitrário, elemento chave da ideologia nacionalista e corporativista do Estado Novo. Nesta perspectiva, o indivíduo existe apenas em virtude da sua pertença a uma determinada cultura nacional e a um determinado grupo social, limitando-se a reproduzir os seus modos de pensar e agir, também estes culturalmente definidos.

A preocupação das autoridades com as questões da "cultura popular" parece pretender elevar o nível moral e intelectual do povo português e exaltar a sua individualidade nacional. Mas, na realidade, trata-se de uma individualidade fabricada pelo ideário do regime, com base na apropriação de estereótipos regionais e imagens da etnografia portuguesa, apresentada por meio de eventos e de encenações simbólicas das tradições populares oficializadas. Os estudos acerca da cultura popular, denominada "folclore", compõem o rosto oficial do povo, recriam festas e costumes, reavivam ou mesmo inventam tradições que se identificam com a visão que o Estado Novo procura perpetuar do quotidiano popular português.

Com efeito, os orgãos oficiais do Estado Novo sempre tentaram elaborar uma determinada imagem tipificada do "ser" português, construída a partir de referências da cultura popular e reelaborada dentro do ideário do regime, tendo em conta as noções de ordem, cidadania e sociedade. Os estudos acerca da cultura popular elaborados por intelectuais do Estado Novo constroem o rosto oficial - e artificial - do povo, destinando-se essencialmente a reavivar ou a criar tradições identificáveis com a visão que as autoridades procuravam transmitir do quotidiano das comunidades, ainda que esta noção estivesse muito distante da realidade de então.

Em Razões Práticas sobre a Teoria da Acção, Pierre Bourdieu argumenta que, se o Estado tem a possibilidade de exercer uma manipulação simbólica, uma reconstrução discursiva da realidade, é porque encarna ao mesmo tempo na objectividade, sob a forma de estruturas e de mecanismos específicos, e também na subjectividade, sob a forma de estruturas mentais, de esquemas de percepção e pensamento. Pelo facto de ser o culminar de um processo que a consolida 
simultaneamente nas estruturas sociais e nas respectivas estruturas mentais, a instituição faz esquecer que proveio de uma longa série de actos organizacionais e apresenta-se com toda uma aparência de naturalidade. Para Bourdieu, o Estado, com os seus mecanismos duradouros de divulgação e imposição de conceitos e divisões segundo as suas próprias estruturas, é por excelência o lugar de concentração e exercício do poder simbólico, de construção de uma verdade paralela, muitas vezes abstraída da realidade histórica.

Os antropólogos e demais estudiosos da sociedade e da cultura devem, por isso, manter-se criticamente atentos à escrita etnográfica que produzem ou sobre a qual se baseiam. Num contexto efectivo de poder simbólico em exercício e de construção de uma verdade paralela, o que fica de fora são, justamente, as práticas reais e contemporâneas do analista. Nestes casos, a etnografia funciona como intermediário entre um regime e o povo, factor cientificamente legitimado de aproximação simbólica e de classificação ideológica de conteúdos.

O Estado Novo adoptou uma postura de clara pretensão redentora e regeneradora da Nação, assumindo a missão de resgatar a raça portuguesa do decadentismo dos períodos liberal e republicano. Este espírito de ruptura com o passado recente propunha uma relação ideológica comprometida com a História. A cultura popular e tradicional, idealizada na sua versão folclórica, seria a solução ideal para tal reorganização da sociedade. As influências ideológicas do regime no texto etnográfico e o serviço por este prestado a essa mesma ideologia oficial estão naturalmente patentes nos textos dedicados à comunidade popular da Ria de Aveiro, principalmente nas décadas de quarenta e cinquenta do século XX.

Um dos títulos mais ilustrativos para esta questão é, de 1940, a obra Vida e Arte do Povo Português, edição do Secretariado da Propaganda Nacional (SPN), coordenada por Francisco Lage, Paulo Ferreira e Luís Chaves, um dos folcloristas oficiais do SPN. Inclui textos sobre temas que vão desde "O Trajar do Povo" e os "Barcos de Portugal” até ao "Carro Rural” e "A Faina do Campo". Esta colectânea de ensaios celebra o espírito do Portugal camponês, cuja paisagem "repele as grandes concepções industriais porque os negros fumos das fábricas lhe repugnam, os fortes ruídos a incomodam, o excessivo materialismo a ofende" ${ }^{30}$.

De acordo com esta ideologia subjacente, e como se tornara já recorrente em quase todos os textos etnográficos em geral e nos da sua autoria em particular, também a contribuição de Rocha Madahil, o ensaio "Barcos de Portugal",

30 QueIroz, C. e SANTos, L. R. (1940). Paisagem e Monumentos de Portugal. Lisboa: Comemorações Centenárias e SPN, p. 7. 
caracteriza as decorações dos moliceiros como sendo uma manifestação de "arte popular ingénua e sadia”31. Na vertente marítima da cultura popular folclorizada procede, de igual modo, à sacralização da tradição, face à perversidade estética e moral do progresso. Como é hábito, é o autor do texto quem dá voz àquilo que ele considera ser a alma do povo, quem descreve as qualidades e conflitos que ele próprio lhe atribuiu, quem determina a superioridade do passado e prevê a decadência do futuro, se o povo ceder às ameaças do progresso mecânico. No entanto, Madahil é cauteloso na localização temporal dessa decadência, que não estará nem tão próxima que desvalorize as práticas populares do presente que se pretende celebrar (sempre o “admirável espírito de sacrifício e heroismo”), nem tão distante que se lhe não adivinhe a ameaça.

Os perigos do progresso e do bem-estar material, inimigos de uma indeterminada riqueza moral e histórica, alimento da alma nacional, encontram-se sintetizados no discurso de António Ferro, de 1939, aquando da entrega do troféu "Galo de Prata" ao vencedor do concurso da "Aldeia mais Portuguesa de Portugal" (que foi Monsanto). Citado e contextualizado por Heloísa Paulo, o discurso de Ferro defende que existem, à data, dois tipos de povos:

[...] uns são os "povos materialistas", "que se agitam no vácuo, que confundem levianamente revoluções com revolução" outros, no entanto, são povos religiosos, povos estóicos, que não se importam de sofrer desde que a grandeza exterior ou interior não sofra abalo, desde que o seu contorno físico no mapa do Mundo não se transforme numa linha pontuada, tremida, desde que a sua alma não passe fome. Estes, conclui, são os povos mais ricos, porque são aqueles que se alimentam de Infinito. Para o director do SPN, o povo português pertence à segunda classificação. ${ }^{32}$

No conjunto de ensaios que compõem Vida e Arte do Povo Português, "Arte Popular”, de Luís de Pina, parece ser o mais fiel ao projecto ideológico expresso por António Ferro, com uma retórica de defesa exacerbada daquilo que o autor considera ser a pureza da arte popular, onde inclui o exemplo do moliceiro. A defesa das "Belas-Artes Populares" é, para Luís de Pina, "uma tarefa nacional", "dever nacional” que "merece a atenção do Govêrno", assumindo assim plena

\footnotetext{
${ }^{31}$ Madahil, R. (1940). “Barcos de Portugal”. Em Lage, F. (ed.). Vida e Arte do Povo Português. Lisboa: Secretariado da Propaganda Nacional, p. 60.

${ }^{32}$ PAUlo, H. (1994). Estado Novo e Propaganda em Portugal e no Brasil: o SPN/SNI e o DIP. Coimbra: Minerva, p. 117.
} 
sintonia com o conceito de folclore do Estado Novo, na sua estratégia geral de redenção e regeneração da Nação, como se de uma campanha militar se tratasse ${ }^{33}$.

O inimigo visado é a industrialização da arte popular (elevada agora a "belaarte”), imagem metonímica dos "povos materialistas" de António Ferro e da "lei inelutável do Progresso, que tudo transforma e avassala" de Rocha Madahil ${ }^{34}$. A arte é o povo e vice-versa e há que defender a todo o custo a pureza e a imutabilidade de ambos. As origens míticas espelhadas directamente na tradição ilustram "o sentido da lusitanidade, que é a própria e pura alma da Nação". Defender esse território espiritual acaba por ser sinónimo de defesa do próprio território nacional, das fronteiras da alma lusitana. A proximidade entre o texto etnográfico e o manifesto político é aqui flagrante: “As velhíssimas fontes de muita da arte popular portuguesa são outros tantos documentos materiais e espirituais que provam a sequente evolução dos Portugueses, a linha recta donde provém, de épocas arcaicas, o sentido de lusitanidade, que é a própria e pura alma da Nação!”35. A arte popular conterá, por isso, elementos de diferenciação étnica, como se assume na passagem: "Nesse particular se encontram diferenças étnicas notáveis. Basta ver-se a arte decorativa de um papua, de um esquimau, de um

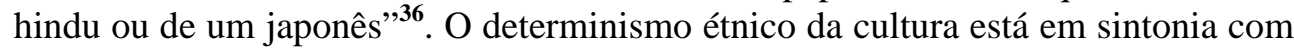
as ideologias em voga na Europa na década de quarenta.

Mas a retórica de Luís de Pina é muito mais directa e agressiva do que a de Ferro e Madahil, radicalizada num discurso bipolar, entre a bondade da tradição e os malefícios do progresso. No entanto, esta bipolarização não é equilibrada: o investimento retórico na crítica do progresso é visivelmente superior ao do louvor da tradição. As "belas-artes populares" são essencialmente conotadas com a noção de "pureza" e seus derivados, ao passo que a sua conversão ao "comércio e indústria" motiva todo um elenco de adjectivos, advérbios, substantivos e verbos de intensa conotação disfórica. "Inventar" ganha aqui semas próximos de “desfigurar”, "adulterar”, "abastardar”, sendo estes dois últimos verbos com forte carga moral. No entanto, não se encontra aqui uma clara argumentação, uma fundamentação para tal série de críticas ou uma exemplificação com casos concretos. A marca da indústria "anda por aí" e "não há mais que dizer",

33 PinA, L. (1940). “Arte Popular”. Em Lage, F. (ed.). Vida e Arte do Povo Português. Lisboa: Secretariado da Propaganda Nacional, pp. 69-70.

${ }^{34}$ Madahil, R. (1940). "Barcos de Portugal”. Em Lage, F. (ed.). Vida e Arte do Povo Português. Lisboa: Secretariado da Propaganda Nacional, p. 61.

35 PinA, L. (1940). “Arte Popular”. Em Lage, F. (ed.). Vida e Arte do Povo Português. Lisboa: Secretariado da Propaganda Nacional, p. 81.

${ }^{36}$ Idem, p. 70. 
simplesmente. A vaga distinção entre o "artista” e o "artífice” leva a pressupor a superioridade mais moral do que artística do primeiro que, presume-se, se encontra ao serviço (fiel) dessa alma nacional que urge preservar.

A indefinição prossegue na descrição da própria arte popular, onde o autor defende, numa sequência algo contraditória, tanto a carência como a existência de uma "concepção artística do desenho": "Muita vez, vezes sem conta, o desenho é mau, incorrecto, inestético: é a côr, é a tinta sòmente, o factor mais decisivo na estética popular. Ela, a côr, substitue, na aparência enganosa, a carência duma concepção verdadeiramente artística do desenho! Não quere isto dizer que esta não exista e, até muito abundantemente" ${ }^{\text {"37 }}$. O juízo de valor simplista "mau, incorrecto, inestético" e a afirmação da "aparência enganosa" da cor parecem contradizer a reiterada valorização da "ingenuidade" do produto artístico. Pina leva ao extremo a simplificação da arte popular, a necessidade de retirar-lhe toda a sofisticação, para melhor a aproximar do ideal folclórico. No entanto, tal esforço retórico detem-se a um passo da inversão de papéis, da transformação do simples em grosseiro. Afirma a imperfeição e o erro para logo dar os "cuidados" como inimigos da "originalidade ou espontaneidade".

Fiel aos seus objectivos mais políticos do que etnográficos, Luís de Pina referese à existência de "alusões político-sociais: bustos de Salazar, legionários, filiados da Mocidade Portuguesa” nos painéis do barco moliceiro, figurações que, na verdade, nunca ocorreram. Mas, logo de seguida, mostra-se atento à realidade, na descrição sem censura que faz de alguns motivos subversivos e obscenos recorrentes na arte popular: "O artista caricatura outros indivíduos: os corcundas, os obesos, os padres, etc. Outras vezes, a obscenidade apimenta a arte: o homem que defeca; o Zé povinho cruzando os antebraços, de punhos fechados; a mulher de saia levantada” ${ }^{38}$. O nacionalismo saudosista, visível nestes e noutros textos de Vida e Arte do Povo Português, propunha-se reestabelecer o esplendor do passado histórico e substituir as influências do estrangeiro e da modernidade pela exaltação das manifestações culturais que reflectissem a verdadeira alma nacional. Porém, apesar de se dirigir ao conjunto da população nacional, a arte popular enquanto símbolo étnico, ético e nacional é, na realidade, objecto de apropriação selectiva por parte da cultura oficial e elitista, para a qual simboliza a sua própria percepção do sentimento nacional.

${ }^{37}$ Idem, p. 71.
${ }^{38}$ Idem, p. 72. 
Os textos etnográficos utilizam a cultura popular, associada às "verdades" ideologicamente marcadas, para redifinir a situação do indivíduo, atribuindo-lhe funções sociais clara e irreversivelmente demarcadas no tempo e no espaço. O esforço do regime para ordenar a Nação, em termos espaciais, ideológicos e sociais é evidente na constante descrição laudatória das províncias (metropolitanas e ultramarinas) e suas características vagas, artificiais mas distintivas; na generalização das crenças e costumes do colectivo "povo"; na rigorosa distribuição, divisão e hierarquização dos papéis sociais. Nada é deixado ao livre arbítrio do actor social, tudo é predeterminado e aceite com alegria singela, espírito de sacrifício e honrada resignação, segundo o discurso oficial. E o discurso oficial é confirmado e perpetuado pelo texto etnográfico, testemunho da ciência ao serviço de uma verdade construída que é necessário credibilizar.

A ordenação espacial e ideológica da Nação exige que a cultura popular, sinónimo de tradição, seja representada nas obras de teor etnográfico como algo de imutável, sujeito a uma matriz ruralista. Não há interesse na interacção nem no progresso, apenas na conservação de um repositório de usos e costumes, em que o estatismo substituiu irremediavelmente a dinâmica cultural. A conservação da ordem e a defesa da identidade nacional são a justificação central para este tipo de discurso:

Em nosso tempo e por toda a parte, as aldeias e os campos constituem o refúgio do elemento nacional, expulso das cidades que assimilaram o figurino cosmopolita. E não só o pitoresco de cada povo se vai progressivamente confinando nessa área, como nela tende a circunscrever-se a zona em que domina o apêgo aos costumes tradicionais, a fidelidade ao imemorial. $^{39}$

As representações e discursos construídos pelo regime e difundidos por uma mundividência maniqueísta e categorizadora, ofereciam a imagem de um espaço de lusitanidade (sociedade, família, papéis dos géneros, trabalho, território, religião, valores morais) perfeitamente ordenado, definitivo e inquestionável. A influência directa de tais representações e discursos actuou até 1974 mas a influência indirecta perdura visivelmente na actualidade, uma vez que os educandos de então são os educadores de hoje, reproduzindo ainda e, muitas vezes, de forma passiva e acrítica os ensinamentos colhidos na infância e/ou ao longo da vida, tão atraentes pela sua simplicidade, guias de um universo sem dúvidas, opções ou

\footnotetext{
${ }^{39}$ Fernandes, A. J. C. (1947). Enfrentando o Destino das Casas do Povo. Lisboa: Junta Central das Casas do Povo, p. 15.
} 
individualidade. E nesta cómoda passividade reside a perversa atracção das ditaduras, como a que dominou e doutrinou Portugal durante mais de meio século.

\section{CONCLUSÃO}

Da leitura de todos estes textos etnográficos se infere que as tradições populares portuguesas são alegorizadas como testemunho e herança histórica, étnica e ética, de que o povo asseguraria a custódia. Nestes textos, tenta-se obter um efeito etnográfico, da mesma forma que, na ficção romanesca, se procura o efeito do real. Ou seja, procura-se um efeito de linguagem etnográfica. Se tal construção é literariamente concebível e poeticamente aceitável, é porém contestável do ponto de vista científico ou positivo, pois não permite (ou não se preocupa com) a verificação nem questiona a sua semelhança com a realidade, de tal modo se preocupa apenas com a verosimilhança, a retórica e a alegorização. Inscrevem-se naquilo que Gérard Genette chama de hipertextualidade, termo que designa todos os textos derivados de um texto anterior por simples transformação ou imitação.

Admitindo, como Philippe Lejeune, que todo o texto etnográfico comporta um pacto referencial explícito, ele comportará igualmente um pacto auto-referencial: o autor esteve em determinado local, em determinado momento, em determinadas condições. Mas nem sempre este pacto é respeitado nos textos etnográficos sobre o barco moliceiro e o universo lagunar. Por vezes, a simples identidade do etnógrafo parece ser a única garantia da veracidade que o texto propõe. Citar uma autoridade precedente equivaleu durante muito tempo ao trabalho de campo ou à consulta de fontes científicas, prática que perpetuou observações nem sempre coincidentes com a realidade.

Os etnógrafos aqui referenciados raramente se interrogaram sobre o seu próprio trabalho. Textos como os de Teófilo Braga ou Rocha Madahil são maioritariamente relatos originados por breves estadias ou passeios na região, que conferiram o direito ao observador " culto" de dissertar sobre o local visitado. As memórias constituem outros tantos exemplos de testemunhos etnográficos, com todos os riscos inerentes ao género, algo que, tratando-se de uma prática que exige rigor científico e factual, transforma uma voz amadora numa voz sábia, pseudocientífica. Para este tipo de pesquisa não há um método único mas antes um constante movimento entre diversos tipos de testemunhos: a observação do presente, a reconstituição do passado, a recordação transmitida ou vivenciada, as fontes escritas, a leitura da paisagem.

Originalmente, o texto etnográfico consistiu na narração de uma experiência de terreno entre povos que não conheciam a escrita e que, por isso, se dizia viverem fora da História. Não sendo esse o caso do contexto lagunar, o etnógrafo 
descreveu-o frequentemente como se de uma realidade distante se tratasse, referindo moliceiros e pescadores como se fossem um outro tipo étnico, com costumes bizarros e longínquos. Muitos dos etnógrafos que compuseram uma visão alegórica das práticas populares portuguesas fizeram de regiões como a Ria de Aveiro verdadeiros territórios exóticos, onde o autor se aventurou para desvendar os seus povos e costumes aos leitores cultos e “civilizados”. Com efeito, trabalhos qualitativos sobre domínios geográficos restritos, como a Ria de Aveiro, tendem a praticar uma etnografia "do pequeno" aspirando a (e conseguindo ser lidos como) uma etnografia “do grande”. O autor procura remediar esta ausência de representatividade através da tentativa de totalização - e de alegorização - a nível da observação, descrição, análise e comentário dos objectos abordados.

No entanto, em The Interpretation of Cultures, Clifford Geertz lembra ao etnógrafo que a sua narração não pode ser mais do que uma interpretação da realidade cultural, realidade que ele não poderá nunca conhecer de forma tão íntima como os membros da sociedade em questão. Há uma diferença entre a cultura, que existe na realidade, e a ciência construída sobre essa cultura, que existe apenas sob a forma de livros ou de conferências, de objectos museológicos ou de documentários. Para Geertz, a autoridade do etnógrafo repousa sobre dois factores ligados à escrita do texto: a experiência, que faz dele a autoridade suprema, e o seu desaparecimento do texto, que lhe confere uma autoridade propriamente científica. As marcas de subjectividade (sob a forma de juízos morais, preconceitos culturais, apontamentos saudosistas ou descrições impressionistas) patentes nas monografias citadas distanciam-nas dessa noção de narrativa etnográfica.

Na sequência do aqui exposto, a exploração do moliço na Ria de Aveiro e as representações etnográficas do barco moliceiro denotaram, ao longo do século XX, uma clara tendência para a repetição de padrões retóricos que as situaram invariavelmente enquanto última oportunidade de registar um objecto e um conjunto de práticas antes da sua dissolução pela modernidade ou, então, apresentando-os como genuínos vestígios de uma era perdida de pureza cultural, numa sociedade agora definitivamente em decadência. Estes padrões advêm de uma retórica baseada em oposições binárias entre a tradição e a modernidade, a agricultura e a indústria, o rural e o urbano, o simples e o erudito, em sintonia e entreajuda com o discurso político-ideológico dos poderes instituídos. Mas tais discursos permanecem ainda hoje evidentes na organização do discurso local, dominando com persistência os novos poderes municipais. As novas figuras do poder político local democrático pós-1974 encontram precisamente nestes discursos arcaicos das origens, das tradições e das memórias as ideias essencialistas que, concretizadas em objectos emblemáticos e representações simbólicas, voltam a recriar as heráldicas, temas e retóricas recorrentes que distinguem o seu território. 
Mais do que testemunhos de 'tradição' versus 'modernidade', objectos como o barco moliceiro são actualmente considerados como representantes da identidade e do património cultural de uma comunidade local, intimamente ligada a um ecossistema específico, como é a Ria de Aveiro. No caso presente, os painéis do moliceiro são representações simbólicas inter-semióticas dos valores, práticas e estruturas de pensamento partilhadas pela comunidade. Mas, hoje em dia, as pinturas do moliceiro fazem também parte de uma lucrativa estrutura económica e turística organizada em redor do objecto-barco, que perdeu quase toda a sua anterior função social e económica e foi reinventado enquanto símbolo cultural da Ria de Aveiro. Um símbolo que distingue inequivocamente a região de outras rivais no mapa turístico nacional e internacional.

\section{REFERÊNCIAS BIBLIOGRÁFICAS}

BouRdieu, Pierre ([1994] 1997). Razões Práticas sobre a Teoria da Aç̧ão, trad. Miguel Serras Pereira. Oeiras: Celta Editora.

Braga, Teófilo ([1885] 1985). O Povo Português nos seus Costumes, Crenças e Tradições. Lisboa: Publicações Dom Quixote.

Chaves, Luís (1943). A Arte Popular: Aspectos do Problema. Porto: Portucalense Editora.

ChAVES, Luís (1945). “A Decoração dos Nossos Barcos (Notas de Etnografia)”. Brotéria, vol. XLI: 45-56.

Chaves, Luís (1958). Os Transportes Populares em Portugal: Carros e Barcos (Tipos e Decorações). Lisboa: Fundação Nacional para a Alegria no Trabalho, Gabinete de Etnografia.

Coelho, Adolfo (1896). Exposição Ethnographica Portugueza - Portugal e Ilhas Adjacentes. Lisboa: Imprensa Nacional.

DionísIo, Sant’Anna (1944). Guia de Portugal III - Beira Litoral, Beira Baixa, Beira Alta. Lisboa: Biblioteca Nacional.

Fernandes, António Júlio de Castro (1947). Enfrentando o Destino das Casas do Povo. Lisboa: Junta Central das Casas do Povo.

FerRo, António (1948). Museu de Arte Popular. Lisboa: SNI.

Filgueiras, Octávio Lixa (1981). "Barcos de Pesca de Portugal”. Revista da Universidade de Coimbra, vol. XXVIII: 344-388.

GEERTZ, Clifford (1973). The Interpretation of Cultures. New York: Basic Books.

Gomes, Celestino (1932). Os Motivos de Decoração Ilhavense. Ilhavo: Casa Minerva.

LAGE, Francisco; Paulo FERREIRA; Luís CHAVES, coord. (1940). Vida e Arte do Povo Português. Lisboa: Secretariado da Propaganda Nacional.

LeITÃo, António Nascimento (1944). Aveiro e sua Laguna (Vistos Através do Mundo). Lisboa: Sá da Costa.

LeJeune, Philippe (1975). Le Pacte Autobiographique. Paris: Seuil.

LimA, Fernando de Castro Pires de, dir. (1968). A Arte Popular em Portugal, vol. II. Lisboa: Editorial Verbo. 
Lourenço, Eduardo (1978). O Labirinto da Saudade: Psicanálise Mítica do Destino Português. Lisboa: Dom Quixote.

MADAHIL, António Gomes da Rocha (1934). Etnografia e História: Bases para a Organização do Museu Municipal de Ílhavo. Ílhavo: Tipografia Casa Minerva.

MADAHIL, António Gomes da Rocha (1947). “A Exposição Alusiva à Ria de Aveiro projectada em 1896 pelo Barão de Cadoro e pelo Engenheiro Melo de Matos”. Arquivo do Distrito de Aveiro, vol. XIII: 1-23.

MagalhãEs, Luís de (1905). “Os Barcos da Ria de Aveiro”. Portugália: Materiaes para o Estudo do Povo Portuguez, tomo II - 1: 4-62.

Paulo, Heloísa (1994). Estado Novo e Propaganda em Portugal e no Brasil: o SPN/SNI e o DIP. Coimbra: Minerva.

Paulo, Heloísa (1994). "Vida e Arte do Povo Português: uma visão da sociedade segundo a propaganda oficial do Estado Novo”. Revista de História das Ideias, vol. 16: 105-134.

Rivals, Claude (1988). "Peintures des Moliceiros d'Aveiro (Portugal): Culture et Arts Populaires”. Revue Géographique des Pyrénées et du Sud-Ouest, tome 5, fasc. 2-3.

Sarmento, Clara (2000 [1999]). Os Moliceiros da Ria de Aveiro: Quadros Flutuantes. Aveiro: Câmara Municipal de Aveiro.

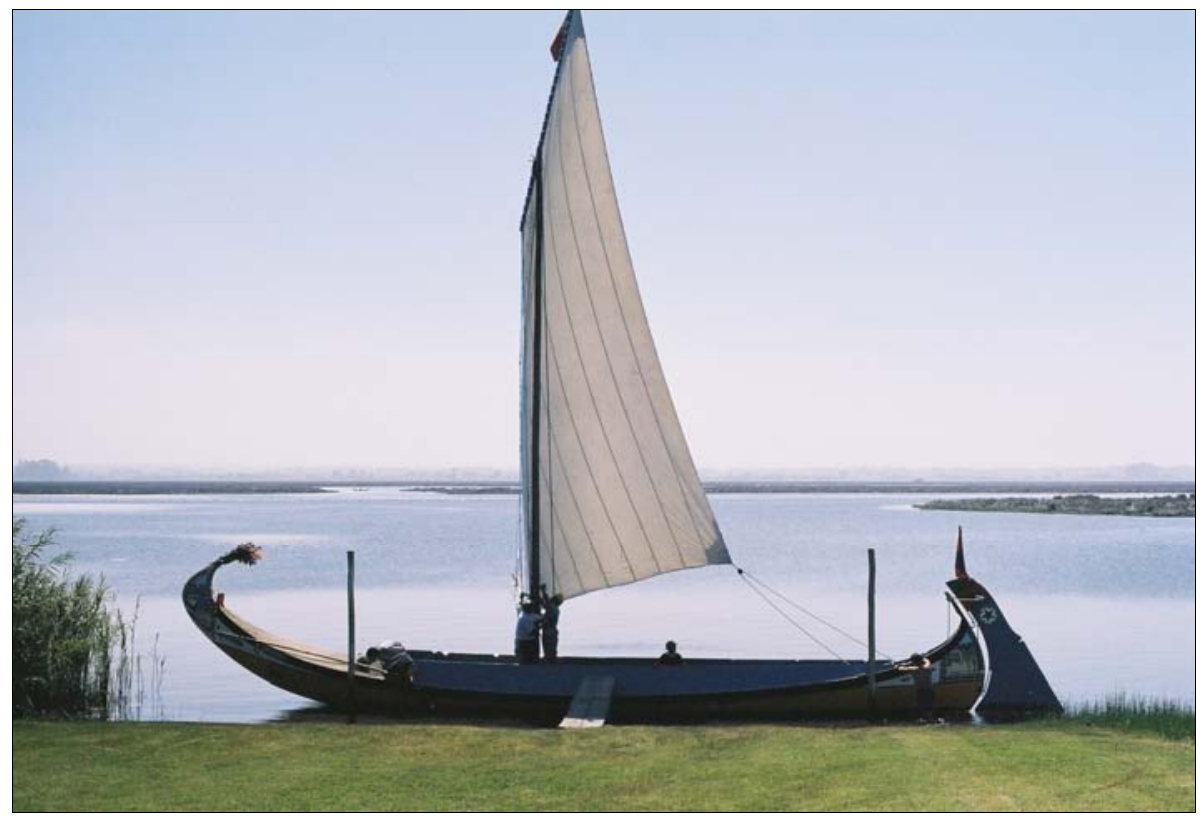

Imagem 1: Barco moliceiro, 2007 (fotografia da autora) 


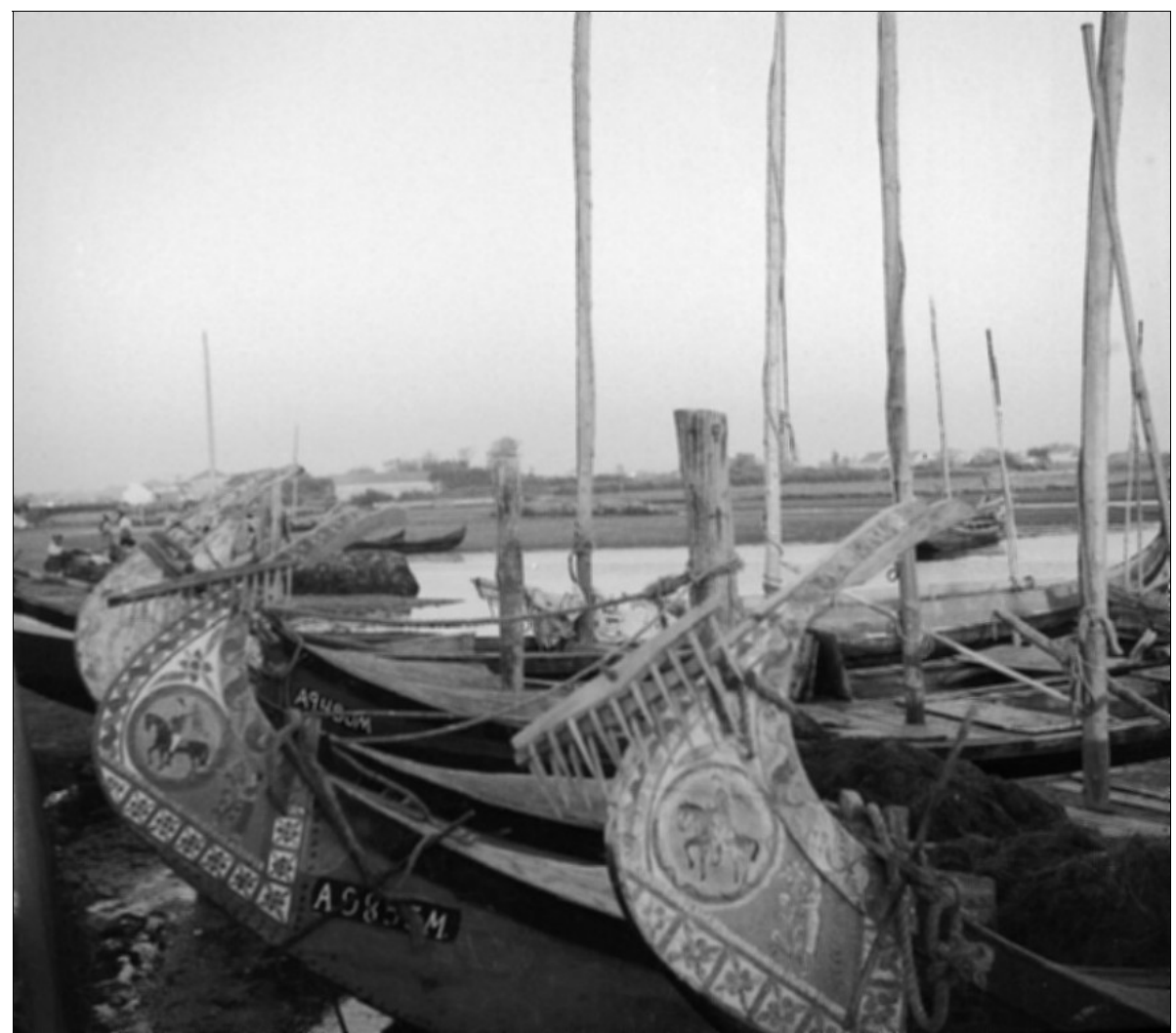

Imagem 2: Moliceiros abicados, com os ancinhos à proa (década de 1950). Legenda do painel em primeiro plano: “Andar se passa a vida. Bestida 13-6-1955”. Fundo Documental do Secretariado Nacional de Informação, Cultura Popular e Turismo, Centro Português de Fotografia, Arquivo de Fotografia de Lisboa. 